\title{
IODP Expedition 324: Ocean Drilling at Shatsky Rise Gives Clues about Oceanic Plateau Formation
}

\author{
by William W. Sager, Takashi Sano, Jörg Geldmacher, and \\ the IODP Expedition 324 Scientists
}

\begin{abstract}
Integrated Ocean Drilling Program (IODP) Expedition 324 cored Shatsky Rise at five sites (U1346-U1350) to study processes of oceanic plateau formation and evolution. Site penetrations ranged from $191.8 \mathrm{~m}$ to $324.1 \mathrm{~m}$ with coring of $52.6 \mathrm{~m}$ to $172.7 \mathrm{~m}$ into igneous basement at four of the sites. Average recovery in basement was $38.7 \%-67.4 \%$. Cored igneous sections consist mainly of variably evolved tholeiitic basalts emplaced as pillows or massive flows. Massive flows are thickest and make up the largest percentage of section on the largest and oldest volcano, late Jurassic age Tamu Massif; thus, it may have formed at high effusion rates. Such massive flows are characteristic of flood basalts, and similar flows were cored at Ontong Java Plateau. Indeed, the simi-
\end{abstract}

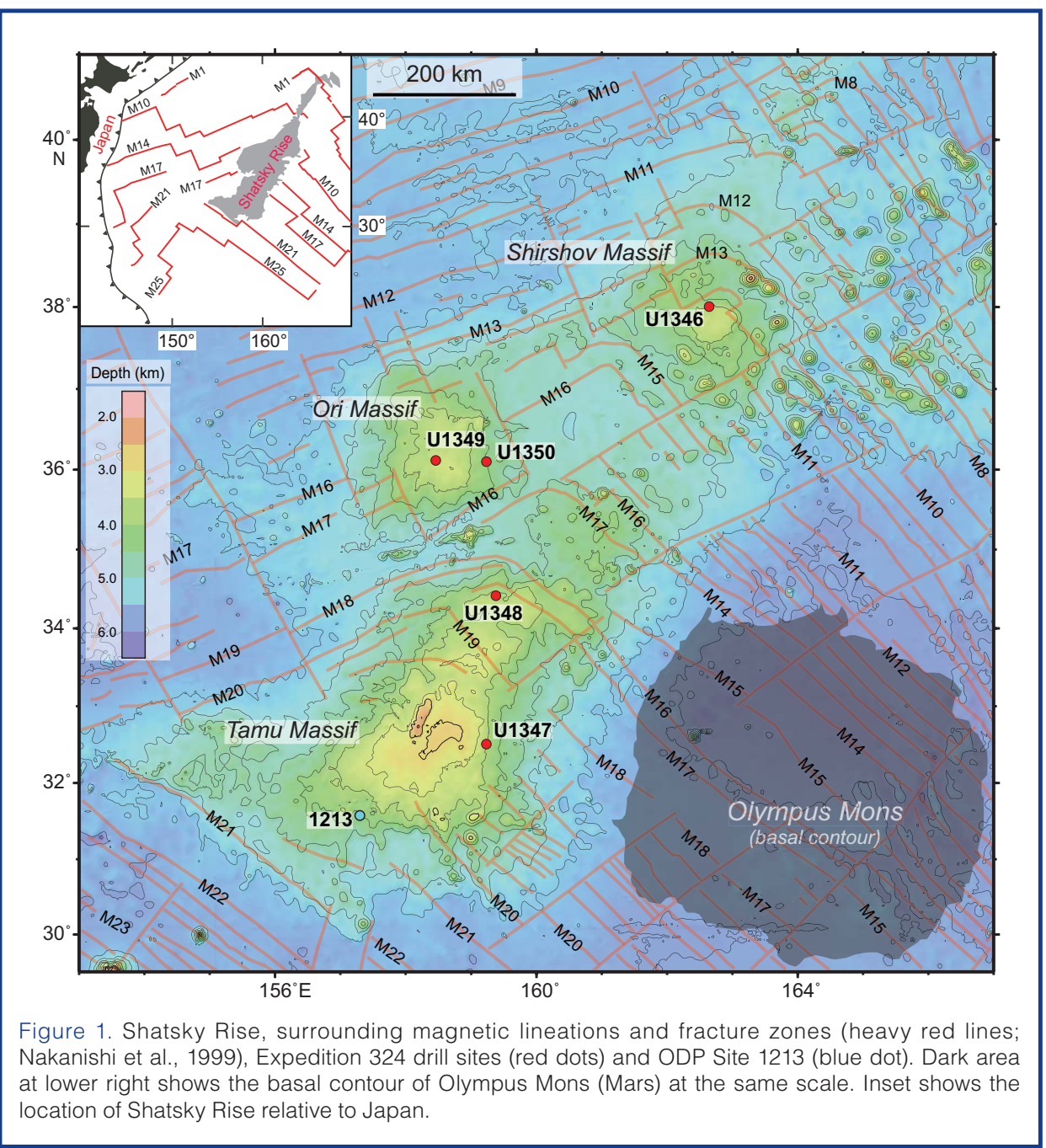

larity of igneous sections at Site U1347 with that cored on Ontong Java Plateau implies similar volcanic styles for these two plateaus. On younger, smaller Shatsky Rise volcanoes, pillow flows are common and massive flows thinner and fewer, which might mean volcanism waned with time. Cored sediments from summit sites contain fossils and structures implying shallow water depths or emergence at the time of eruption and normal subsidence since. Summit sites also show pervasive alteration that could be due to high fluid fluxes. A thick section of volcaniclastics cored on Tamu Massif suggests that shallow, explosive submarine volcanism played a significant role in the geologic development of the plateau summit. Expedition 324 results imply that Shatsky Rise began with massive eruptions forming a huge volcano and that subsequent eruptions waned in intensity, forming volcanoes that are large, but which did not erupt with unusually high effusion rates. Similarities of cored sections on Tamu Massif with those of Ontong Java Plateau indicate that these oceanic plateaus formed in similar fashion.

\section{Introduction}

Large outpourings of basalt have occurred widely around the globe (Coffin and Eldholm, 1994). The greatest of these "large igneous provinces" (LIPs) produced continental flood basalts on land and oceanic plateaus under the sea (Duncan and Richards, 1991), the largest with volumes in millions of cubic kilometers. Plateau-building magmas must come from the mantle, but source depth and emplacement mechanisms are unclear. A widely held view is that plateaus form when the head of a nascent mantle plume-a huge thermal diapir from the lower mantle-rises to the surface, causing massive volcanic eruptions and sub-crustal intrusion (Duncan and Richards, 1991). An alternative explanation is that plateau erup- 
tions come from decompression melting of unusually fusible upper mantle at plate edges (Foulger, 2007). This explanation is bolstered by the observation that many plateaus formed near ocean ridges, especially at triple junctions, a situation that is unlikely if the volcanism results from deep mantle convection independent of plate tectonics (Sager, 2005).

Aside from uncertainty about source mechanism, the processes of ocean plateau volcanism are poorly understood because few plateaus have been sampled extensively. Massive eruptions are deduced mainly from the size of plateau edifices coupled with inferred short eruption periods (Coffin and Eldholm, 1994). In addition, it is suggested that low oceanic plateau flank slopes imply high eruption rates and long flows similar to continental flood basalts (Keszthelyi and Self, 1998; Sager et al., 1999). Ocean Drilling Program (ODP) cruises have sampled the largest oceanic plateaus, Kerguelen (Leg 183; Coffin et al., 2002) and Ontong Java (Leg 192; Mahoney et al., 2001), and they have found that massive lava flows are common. A problem for these studies is that these plateaus formed mostly during the Cretaceous Quiet Period when there were no magnetic reversals to record the positions of mid-ocean ridges, so it is unclear how plate boundaries may have factored into their formation (Sager et al., 1999).

In contrast, Shatsky Rise (Fig. 1) is a large Pacific plateau (area $\sim 4.8 \times 10^{5} \mathrm{~km}^{2}$; Sager et al., 1999) with a clear tectonic setting. It erupted at a triple junction during the late Jurassic and Early Cretaceous and stretches over $\sim 1700 \mathrm{~km}$ with three principal volcanic massifs: Tamu, Ori, and Shirshov (Fig. 1; Sager et al., 1999). Tamu Massif erupted at $145 \mathrm{Ma}$ (Mahoney et al., 2005). Other volcanic edifices must be younger than Tamu Massif because the lithosphere on which they repose is younger. Furthermore, isostatic compensa- tion and interaction with spreading ridges imply that these edifices formed at the time the lithosphere was created, which means they are younger toward the northeast (Sager et al., 1999). Although some aspects of Shatsky Rise appear consistent with the plume head hypothesis, others are not. Emplacement apparently began with the construction of a huge volcanic edifice, Tamu Massif $\left(\sim 2.5 \times 10^{6} \mathrm{~km}^{3}\right)$, which possibly erupted in $<1 \mathrm{Myr}$, coincident with an $\sim 800$-km jump of the triple junction (Nakanishi et al., 1999; Sager et al., 1999; Sager, 2005). Tamu Massif appears to be a large, central "supervolcano" with an area similar to that of Olympus Mons on Mars (Fig. 1), which is widely considered the largest volcano in the solar system. Subsequent volcanoes (Ori and Shirshov massifs) are significantly smaller (each $\sim 25 \%$ the size of Tamu Massif), and together with a low volcanic ridge at the north end of the plateau, they may imply a transition from plume head to tail (Sager et al., 1999). Apropos of plate-edge genesis, Shatsky Rise displays a connection with 
triple junction tectonics that is repeated elsewhere in the Pacific (Sager, 2005). Moreover, basalts from ODP Site 1213 (ODP Leg 198), on Tamu Massif (Fig. 1), have isotopic characteristics similar to mid-ocean ridge basalt (MORB) (Mahoney et al., 2005).

Shatsky Rise was cored on IODP Expedition 324 because it has characteristics that can be attributed to both a mantle plume and ridge tectonics; thus, it is an excellent location to investigate the formation of oceanic plateaus. Here, we present a review of initial findings and insights from cores and logs collected during Expedition 324.

\section{Drilling Overview}

Expedition 324 drilled at five sites on Shatsky Rise (Fig. 1; Sager et al., 2010) to examine changes in volcanism along the presumed age trend. Site U1347 was cored to $317.5 \mathrm{~m}$ below the seafloor (mbsf), including $159.9 \mathrm{~m}$ of igneous basement consisting of submarine basalt flows (Fig. 2). This site and Site 1213 , which penetrated $46.6 \mathrm{~m}$ of basalt on ODP Leg 198 (Shipboard Scientific Party, 2002), both sampled the upper flanks of Tamu Massif, the oldest edifice. Drilling at Site U1348, on the north flank of Tamu Massif, targeted a large basement high, recovering a 120 -m-thick section of highly altered volcaniclastic sediments. Farther north, sites U1349 and U1350 were situated to sample the summit and flank of Ori Massif. Drilling at Site U1349 penetrated to $250.4 \mathrm{mbsf}$ and $85.3 \mathrm{~m}$ into igneous basement, recovering highly altered subaerial or shallow-water lava flows. At Site U1350, coring proceeded to $315.8 \mathrm{mbsf}$, with the last $172.7 \mathrm{~m}$ being in a section of slightly to moderately altered submarine lava flows. On the Shirshov Massif summit, Site U1346 penetrated to $191.8 \mathrm{mbsf}$, coring $52.6 \mathrm{~m}$ of moderately to highly altered basalt flows.

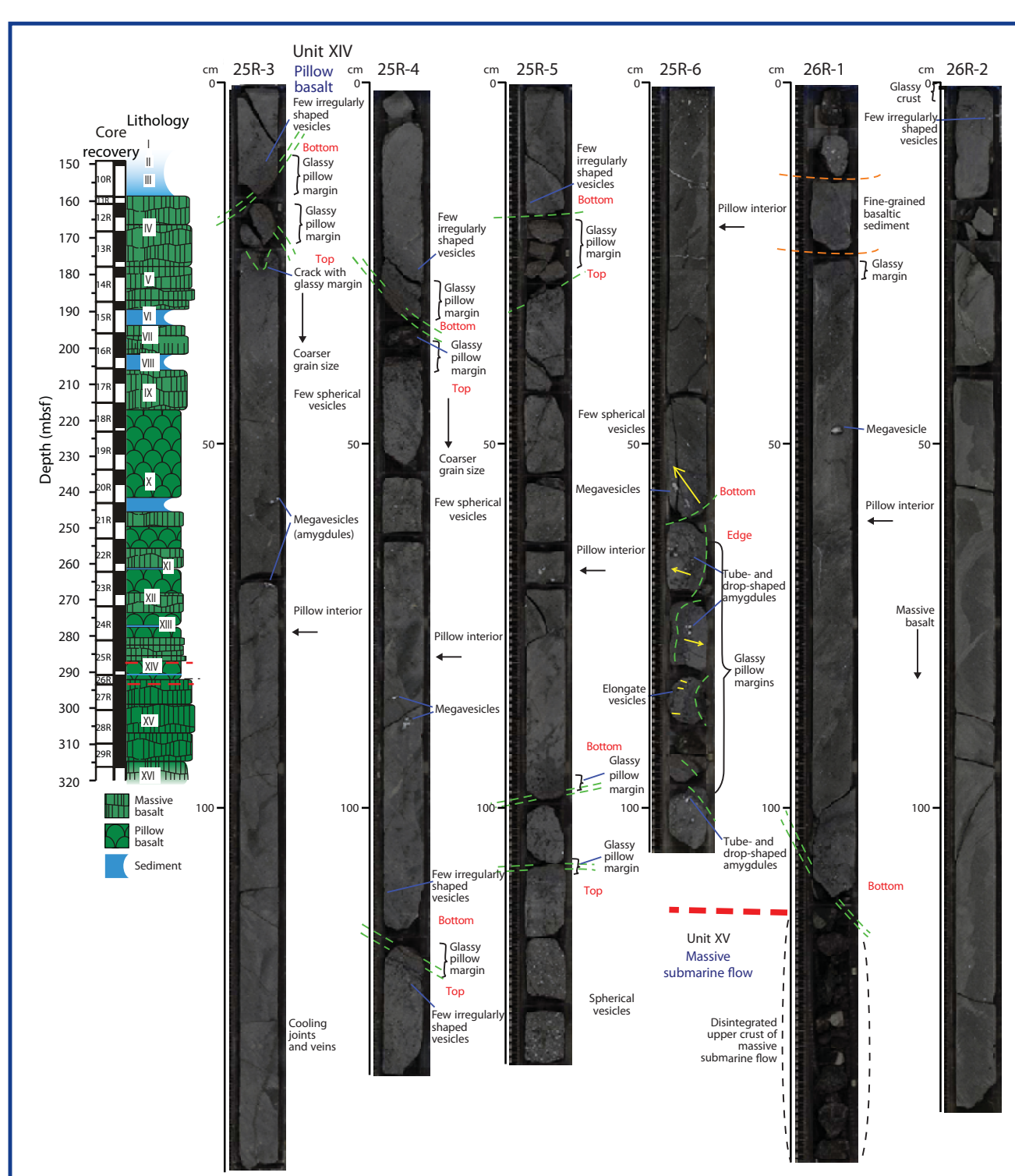

Figure 3. Core images showing pillow lavas and massive flows from Site U1347. The images are annotated with volcanological features and show a section spanning the transition between the lower pillow basalts (Unit XIV) and upper part of a massive basalt flow (Unit XV) from Sections 324-U1347A-25R-3 through 26R-2, Hole U1347A. Red dashed lines = lithologic unit boundaries, red text = top and bottom of pillow lobes, dashed green lines = glassy chilled margins. Dashed lines in lithologic column (left) show location of core sections portrayed.

\section{Igneous Rocks}

The signature structures of igneous rock sections cored on Shatsky Rise are pillow lavas $0.2-1.0 \mathrm{~m}$ in diameter and massive inflation flows up to $23 \mathrm{~m}$ thick (Figs. 2, 3). Both types of cooling units were distinguished in cores by the presence of chilled margins and internal vesicle patterns. Pillows are typical of submarine eruptions at low effusion rates and are often found on seamounts and mid-ocean ridge flanks (Ballard et al., 1979). Massive flows are characteristic of continental flood basalt provinces, and they indicate a high effusion rate (Jerram and Widdowson, 2005). They are formed by inflation of the massive interior as an elastic skin develops on the upper and lower chilled margins (Self et al., 1997). Similar massive flows were cored at ODP Sites 1185 and 1186 on the Ontong Java Plateau (Mahoney et al., 2001). In addition, we reinterpret three igneous units cored at Site 1213 on Tamu Massif, previously thought to be sills (Shipboard Scientific Party, 2002), as massive flows 8-15 m thick (Fig. 2; Koppers et al., 2010). 
The pattern of igneous activity appears to change across Shatsky Rise. At Tamu Massif, massive flows dominate. The Site U1347 section consists of two pulses of massive flows separated by a $\sim 75 \mathrm{~m}$ interval of mostly pillow flows. In total the igneous section contains $\sim 33 \%$ pillows. This section is almost indistinguishable from that cored on Ontong Java Plateau at Site 1185 . Approximately $220 \mathrm{~km}$ away at Site 1213 , only massive flows were recovered. On the north side of Shatsky Rise at Shirshov Massif, the Site U1346 section is $90 \%$ pillows, with only two larger cooling units $(1.9 \mathrm{~m}$ and $3.2 \mathrm{~m}$ thick) recognized. In between, at Ori Massif, the proportion of massive units appears intermediate. No pillows were recognized in the short Site U1349 section, but the thin massive flows there were emplaced near or above sea level, and none approaches the thickness of those on Tamu Massif. The Site U1350 section contains a mixture of flow types but consists of $\sim 86 \%$ pillow units, and massive units are intermediate in thickness $(\leq 6 \mathrm{~m})$. It thus seems that volcanism at Tamu Massif was unusually effusive, with activity typical of the largest ocean plateaus and flood basalts, but the effusion rate apparently waned with time such that flow characteristics on Ori and Shirshov Massifs were similar to those of large seamounts, such as the Emperors (Tarduno et al., 2002).

Cores from Site U1348 imply that explosive volcanism played an important role in building Shatsky Rise. The 120 -m-thick igneous section at that site consists almost entirely of compacted, highly altered volcanic glass fragments, ranging from principally submarine hyaloclastite to redeposited volcaniclastic turbidites (Fig. 2). This finding suggests that other basement highs and cones are composed of similar volcaniclastic materials.

The majority of igneous rocks from Sites U1346, U1347, U1348, and U1350 are plagioclase-clinopyroxene (micro) phyric basalts. The least-altered basalts (recognized by $<3.2 \mathrm{wt} \%$ volatile loss on ignition, LOI) are from Sites U1346, U1347, and U1350, and are variably evolved tholeiites (Fig. 4). Similar to basalts from Site 1213 (Mahoney et al., 2005), their compositional ranges overlap those of MORB and Ontong Java Plateau basalts. Overall, they are slightly enriched in incompatible elements compared to normal MORB, showing some resemblance to enriched-type MORB. In contrast, lavas from Site U1349 are Cr-spinel-bearing,
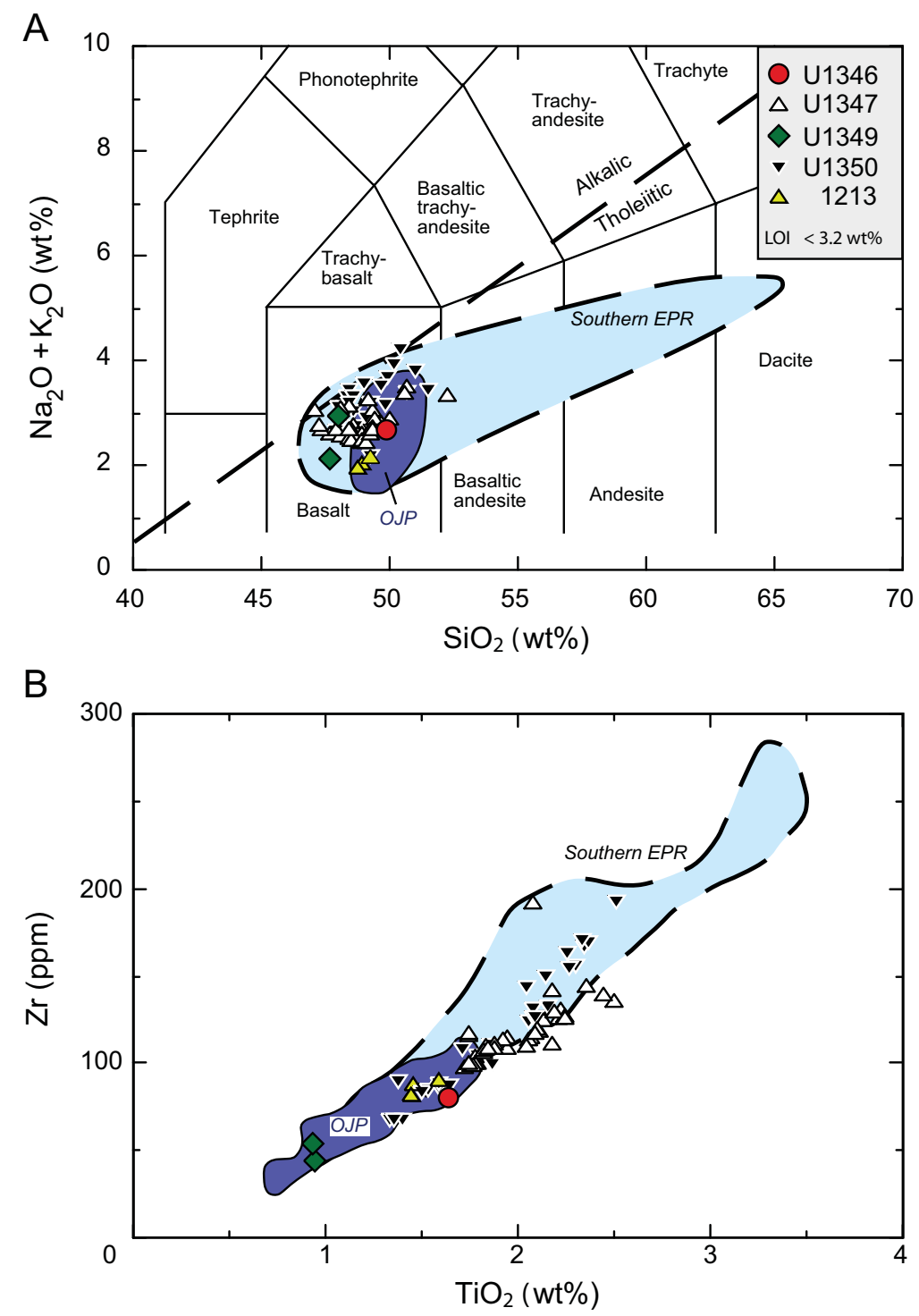

Figure 4. Chemical characteristics of Shatsky Rise basalt samples. [A] Total alkalis vs. silica for least-altered samples with rock classification of Le Maitre et al. (1989). Dashed ine divides Hawaiian tholeiitic and alkalic lavas. All data are normalized to $100 \mathrm{wt} \%$ totals. [B] $\mathrm{TiO}_{2}$ vs. Zr. Site 1213 data are from Mahoney et al. (2005). OJP = Ontong Java Plateau (data of Tejada et al., 1996, 2002; Fitton and Godard, 2004), EPR = East Pacific Rise (data of Sinton et al., 1991; Bach et al., 1994; Mahoney et al., 1994). 
ative of interaction with S-rich hydrothermal fluids. Site U1348 hyaloclastites are all highly altered, mostly converted to palagonite and cemented with calcite and/or zeolites. Basalts recovered at Site U1349 were affected by extensive water-rock interactions at varying temperatures and redox conditions with depth. Some samples from this site appear to record alteration under subaerial, oxidative conditions. The common aspect of all three sites, aside from being at bathymetric highs, is that the alteration implies significant fluid flow.

\section{Sediments and Sea Level}

In previous drilling, Shatsky Rise sediments were found to be dominantly pelagic carbonate sediments (ooze, chalk, limestone) with chert in the Mesozoic section. Expedition 324 drilling recovered a variety of sediment types from four of five sites (Figs. 2, 5) providing clues about depositional environments during and shortly after the formation of the volcanic basement, including the finding that some sites were near sea level during deposition. This is true for both sites on Tamu Massif. Radiolarian-bearing volcaniclastic siltstone and sandstones were cored in the $77 \mathrm{~m}$ above the top of basement at Site U1347. These sediments are marked by high content of zeolite and volcaniclastics; they display cross-bedding and intense bioturbation and contain a neritic (<200 m water depth) assemblage of benthic foraminifera. At Site U1348, calcareous sandstones with bioclasts (including material from reef-building fauna), volcanic fragments, and zeolitic clay were recovered. Both sections imply deposition in shallow water near a volcanic source. These findings are consistent with shallow water fossils that were recovered in a dredge haul at a similar depth $\sim 140 \mathrm{~km}$ southwest of Site U1347 (Sager et al., 1999).

Site U1349 on the Ori Massif summit yielded volcanic sandstone, siltstone, claystone, and breccia in the $\sim 30 \mathrm{~m}$ above igneous basement. At the bottom of this interval, a yellow-red clay layer of intensely-weathered basalt fragments, interpreted as a paleosol, indicates probable subaerial exposure under tropical conditions. The presence of montmorillonite and halloysite in this layer also support the interpretation of subaerial conditions. Only $~ 10 \mathrm{~m}$ deeper in the section, an oolitic limestone between lava flows implies a shallow marine environment. No significant non-pelagic sediment was recovered above basement at Site U1350 on the deep Ori Massif flank. Evidently, this site was bypassed by all but pelagic sediment.

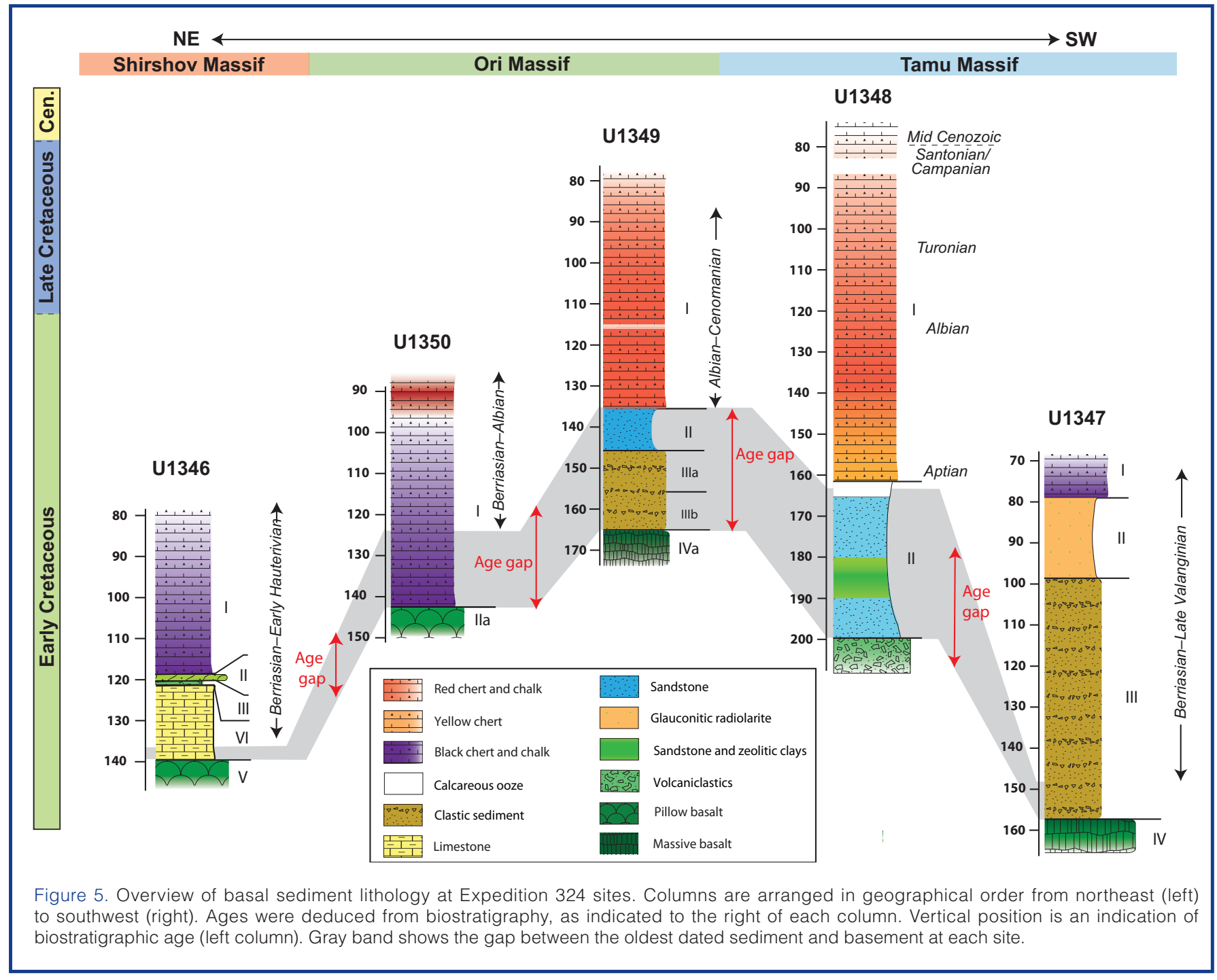


At Site U1346 on Shirshov Massif the bottom $17 \mathrm{~m}$ of the sediment column consists of clayey limestones and calcareous mudstone containing abundant shell fragments, a neritic $(<500 \mathrm{~m}$ water depth) benthic foraminiferal assemblage, and small, probably wood fragments. These sediments are overlain by a short interval of fine-grained volcaniclastic turbidites and a debris flow of intermingled basalt and limestone showing soft-sediment deformation. Altogether, these observations are consistent with deposition in shallow water near forested, volcanic land and subsequent progressive deepening as the volcano subsided.

Sedimentary layers were found intercalated with basalt flows at Sites U1347, U1349, U1350 and at ODP Site 1213 (Shipboard Scientific Party, 2002). At Site U1347, three layers are $\sim 4.5-5.0 \mathrm{~m}$ thick, but all other sedimentary interbeds at this and other sites are much thinner. In general, the interbeds consist of carbonate debris or volcaniclastic sandstone or siltstone, often containing fossil radiolarians. Although we have no reliable age progression data to define sedimentation rates of any interbeds, it appears that all were depos- ited over relatively short periods, implying that hiatuses between lava flows were of short duration, consistent with rapid emplacement of the igneous sections.

\section{Implications}

Although cores from Expedition 324 and prior drilling represent only a small sampling, they provide a clearer picture of Shatsky Rise's geology and give insights for other plateaus. Prior to Expedition 324, we knew that Shatsky Rise must be largely basaltic, but the style of volcanism was unknown. Virtually all sediments previously cored from Shatsky Rise were pelagic, so there was little information about other sedimentary environments or the role of explosive volcanism. Scant evidence existed that the summit of Tamu Massif was originally near sea level. Modestly-altered samples of igneous basement were available from only one site (1213); they exhibited isotopic characteristics similar to MORB (Mahoney et al., 2005), and were described as representing sills. Such characteristics seemed unusual, and their significance was unclear.
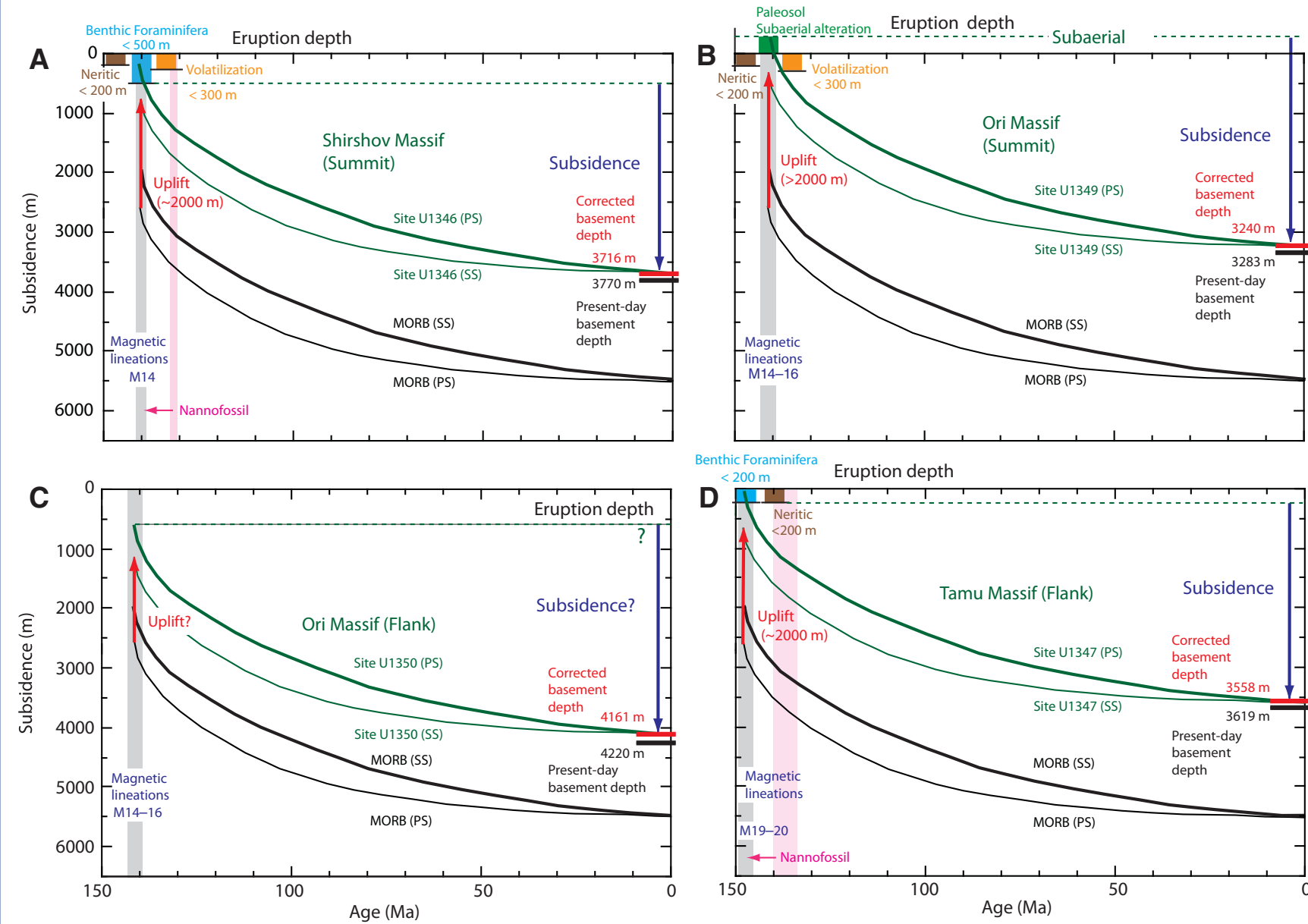

Figure 6. Subsidence curves calculated for Expedition 324 Sites. [A] Site U1346 (Shirshov Massif summit). [B] Site U1349 (Ori Massif summit). [C] Site U1350 (Ori Massif flank). [D] Site U1347 (Tamu Massif flank). Colored curves = extrapolated site depth at the time of eruptions, calculated by backtracking from the present depth (corrected for sediment loading; Crough, 1983) using thermal subsidence models. PS = Parsons and Sclater (1977) model, SS = Stein and Stein (1992) model. Paleodepth estimates from backtracking are compared with paleodepth indicators from Expedition 324 cores. Black curves = subsidence models for normal mid-ocean ridges, red arrow = difference between normal ridge and observed paleodepth, taken as the amount of uplift caused by volcano construction. Magnetic lineation ages are from Nakanishi et al. (1999) using the time scale of Gradstein et al. (2004). 
Expedition 324 provided samples of igneous basement at four new sites, and broadly MORB-like characteristics appear general. Massive flows are found at several locations, and the thickest and greatest percentage of total section are found on Tamu Massif, which is characterized by massive flows similar to those found in continental flood basalt provinces (Jerram and Widdowson, 2005) and Ontong Java Plateau (Mahoney et al., 2001). Because of its large size, shape, and style of volcanism, Tamu Massif appears to be a "supervolcano". It suggests that other oceanic plateaus may have formed from similarly colossal volcanoes. In contrast, massive flows are thinner and less abundant at Ori and Shirshov massifs, whose size and eruption style were probably similar to those of the present island of Hawaiithat is , big but not deserving of superlatives.

Expedition 324 cores suggest that the summits of Shatsky Rise volcanoes were near sea level or perhaps emergent. The large interior of the Tamu Massif summit may have been emergent, perhaps with significant elevation because the basal sediments of Site U1347 were deposited in shallow water, but the top of the volcano is $\sim 800 \mathrm{~m}$ shallower. Site U1349, with evidence of both shallow water and emergence, suggests that the summit of Ori Massif was at the water's edge. Site U1346, located at the edge of a summit platform on Shirshov Massif, also indicates shallow-water sedimentation and implies that volcanic cones in the interior may have been emergent. It is likely that the plateau formed one or more islands through the late Jurassic and Early Cretaceous, but their size and duration are unclear. Backtracked subsidence curves for the sites (Fig. 6) show that the present depth of the top of igneous basement is consistent with that predicted by normal lithospheric subsidence. If there was dynamic uplift during plateau formation, for example, owing to the arrival of a plume head (Coffin and Eldholm, 1994), there is no evidence of it now.

Site U1348 provided a surprise with a thick pile of highly altered hyaloclastite. Prior to Expedition 324, no significant accumulation of such sediment had been recovered from Shatsky Rise. The finding of this material should not be a surprise, given that it is common on seamounts (Smith and Batiza, 1989). The large basement ridge at Site U1348, thought to be the top of a fault block, consists wholly or in part of the products of explosive submarine volcanism. With this discovery, it seems likely that many of the basement highs imaged on seismic sections (Sager et al., 1999) have a similar origin.

The extent of alteration of igneous basement was also a surprise. We thought it was possible to obtain relatively unaltered samples by drilling through the weathered carapace, but heavy alteration occurred throughout the three higher-elevation igneous sections (U1346, U1348, U1349). This finding implies that fluid circulation at the summits of the volcanic edifices was pervasive. Whether this is a result of proximity to sea level, to heat concentration, or of the volcanic structure is unclear. In contrast, flank flows appear to have been armored by subsequent flows, restricting fluid flow and consequent alteration.

Results now available from Expedition 324 are mainly physical descriptions of the processes of volcanism, sedimentation, and evolution of the Shatsky Rise plateau. Resolution of what caused Shatsky Rise formation is not yet feasible but should be closer after careful studies of the recovered samples, especially those involving high-precision age determination and isotopic and geochemical characterization of the igneous basement. Whatever mechanism is called upon to generate this plateau, it must explain the fact that initial eruptions built an enormous volcanic edifice with massive lava flows and rose to sea level during edifice building and subsided normally thereafter. Expedition 324 results also indicate that different parts of oceanic plateaus can have different styles of eruption, with some having characteristics similar to that of normal seamount volcanism elsewhere.

\section{IODP Expedition 324 Scientists}

W.W. Sager (Co-Chief Scientist), T. Sano (Co-Chief Scientist), J. Geldmacher (Staff Scientist), R. Almeev, A. Ando, C. Carvallo, A. Delacour, H.A. Evans, A.R. Greene, A.C. Harris, S. Herrmann, K. Heydolph, N. Hirano, N. Idrissi, A. Ishikawa, G. Iturrino, M.-H. Kang, A.A.P. Koppers, S. Li, K. Littler, J.J. Mahoney, N. Matsubara, M. Miyoshi, D.T. Murphy, J.H. Natland, M. Ooga, J. Prytulak, K. Shimizu, M. Tominaga, Y. Uchio, M. Widdowson, and S. C. Woodard.

\section{References}

Bach, W., Hegner, E., Erzinger, J., and Satir, M., 1994. Chemical and isotopic variations along the superfast spreading East Pacific Rise from $6^{\circ} \mathrm{S}$ to $30^{\circ} \mathrm{S}$. Contrib. Mineral. Petrol., 116:365-380, doi:10.1007/BF00310905.

Ballard, R.D., Holcomb, R.T., and van Andel, Tj.H., 1979. The Galapagos Rift at $86^{\circ} \mathrm{W}$ : Sheet flows, collapse pits, and lava lakes of the rift valley. J. Geophys. Res., 84:5407-5422, doi:10.1029/JB084iB10p05407.

Coffin, M.F., and Eldholm, O., 1994. Large igneous provinces: Crustal structure, dimensions, and external consequences. Rev. Geophys., 32:1-36, doi:10.1029/93RG02508.

Coffin, M.F., Pringle, M.S., Duncan, R.A., Gladczenko, T.P., Storey, M., Müller, R.D., and Gahagan, L.A., 2002. Kerguelen hotspot magma output since 130 Ma. J. Petrol., 43:11211139. doi:10.1093/petrology/43.7.1121.

Crough, S.T., 1983. The correction for sediment loading on the seafloor. J. Geophys. Res., 88:6449-6454, doi:10.1093/ petrology/43.7.1121.

Duncan, R.A., and Richards, M.A., 1991. Hotspots, mantle plumes, flood basalts, and true polar wander. Rev. Geophys., 29:3150. doi:10.1029/90RG02372.

Fitton, J.G., and Godard, M., 2004. Origin and evolution of magmas on the Ontong Java Plateau. In Fitton, J.G., Mahoney, J.J., Wallace, P.J., and Saunders, A.D. (Eds.), Origin and Evo- 
lution of the Ontong Java Plateau, Geol. Soc. Spec. Publ., 229:151-178.

Foulger, G.R., 2007. The "plate" model for the genesis of melting anomalies. In Foulger, G.R., and Jurdy, D.M. (Eds.), Plates, Plumes, and Planetary Processes. Spec. Pap. - Geol. Soc. Am., 430:1-28.

Gradstein, F.M., Ogg, J.G., and Smith, A., 2004. A Geologic Time Scale 2004: Cambridge (Cambridge University Press).

Jerram, D.A., and Widdowson, M., 2005. The anatomy of continental flood basalt provinces: Geological constraints on the process and products of flood volcanism. Lithos, 79:385-405, doi:10.1016/j.lithos.2004.09.009.

Keszthelyi, L., and Self, S., 1998. Some physical requirements for the emplacement of long basaltic lava flows. J. Geophys. Res., 103:27,447-27,464, doi:10.1029/98JB00606.

Koppers, A.A.P., Sano, T., Natland, J.H., Widdowson, M., Almeev, R., Greene, A.R., Murphy, D.T., Delacour, A., Miyoshi, M., Shimizu, K., Li, S., Hirano, N., Geldmacher, J., and the Expedition 324 Scientists, 2010. Massive basalt flows on the southern flank of Tamu Massif, Shatsky Rise: A reappraisal of ODP Site 1213 basement. In Sager, W.W., Sano, T., Geldmacher, J., and the Expedition 324 Scientists, Proc. IODP, 324: Tokyo (Integrated Ocean Drilling Progam Management International, Inc.). doi:10.2204/iodp. proc.324.109.2010.

Le Maitre, R.W., Bateman, P., Dudek, A., Keller, J., Lameyre, J., Le Bas, M.J., Sabine, P.A., Schmid, R., Sorensen, H., Streckeisen, A., Wolley A.R., and Zanettin, B., 1989. A Classification of Igneous Rocks and Glossary of Terms: Oxford (Blackwell Scientific Publications).

Mahoney, J.J., Duncan, R.A., Tejada, M.L.G., Sager, W.W., and Bralower, T.J., 2005. Jurassic-Cretaceous boundary age and mid-ocean-ridge-type mantle source for Shatsky Rise. Geology, 33:185-188, doi:10.1130/G21378.1.

Mahoney, J.J., Fitton, J.G., Wallace, P.J., et al., 2001. Proc. ODP, Init. Repts., 192: College Station, TX (Ocean Drilling Program). doi:10.2973/odp.proc.ir.192.2001.

Mahoney, J.J., Sinton, J.M., Kurz, M.D., Macdougall, J.D., Spencer, K.J., and Lugmair, G.W., 1994. Isotope and trace element characteristics of a super-fast spreading ridge: East Pacific Rise $13-23^{\circ}$ S. Earth Planet. Sci. Lett., 121:173-193, doi:10.1016/0012-821X(94)90039-6.

Nakanishi, M., Sager, W.W., and Klaus, A., 1999. Magnetic lineations within Shatsky Rise, northwest Pacific Ocean: Implications for hot spot-triple junction interaction and oceanic plateau formation. J. Geophys. Res., 104:7539-7556, doi:10.1029/ 1999JB900002.

Parsons, B., and Sclater, J.G., 1977. An analysis of the variation of ocean floor bathymetry and heat flow with age. J. Geophys. Res., 82:803-827. doi:10.1029/JB082i005p00803.

Sager, W.W., 2005. What built Shatsky Rise, a mantle plume or ridge tectonics? In Foulger, G.R., Natland, J.H., Presnall, D.C., and Anderson, D.L. (Eds.), Plates, Plumes, and Paradigms. Spec. Pap.-Geol. Soc. Am., 388:721-733, doi:10.1029/ 1998JB900009.

Sager, W.W., Kim, J., Klaus, A., Nakanishi, M., and Khankishieva, L.M., 1999. Bathymetry of Shatsky Rise, northwest Pacific Ocean: Implications for ocean plateau development at a triple junction. J. Geophys. Res., 104:7557-7576, doi:10.1029/
1998JB900009.

Sager, W.W., Sano, T., Geldmacher, J., and the Expedition 324 Scientists, 2010. Proc. IODP, 324: Tokyo (Integrated Ocean Drilling Program Management International, Inc.), doi:10.2204/iodp.proc.324.2010.

Self, S., Thordarson, T., and Keszthelyi, L., 1997. Emplacement of continental flood basalt lava flows. In Mahoney, J.J., and Coffin, M.F. (Eds.), Large Igneous Provinces. Geophys. Monogr. - Am. Geophys. Union, 100:381-410.

Shipboard Scientific Party, 2002. Site 1213. In Bralower, T.J., Premoli Silva, I., Malone, M.J., et al., Proc. ODP, Init. Repts., 198: College Station, TX (Ocean Drilling Program), 1-110, doi:10.2973/odp.proc.ir.198.109.2002.

Sinton, J.M., Smaglik, S.M., Mahoney, J.J., and Macdonald, K.C., 1991. Magmatic processes at superfast spreading midocean ridges: Glass compositional variations along the East Pacific Rise $13^{\circ}-23^{\circ}$ S. J. Geophys. Res., 96:6133-6155, doi:10.1029/90JB02454.

Smith, T.L., and Batiza, R., 1989. New field and laboratory evidence for the origin of hyaloclastite flows on seamount summits. Bull. Volcanol., 51:96-114, doi:10.1007/BF01081979.

Stein, C.A., and Stein, S., 1992. A model for the global variation in oceanic depth and heat flow with lithospheric age. Nature, 359:123-129, doi:10.1038/359123a0.

Tarduno, J.A., Duncan, R.A., Scholl, D.W., et al., 2002. Proc. ODP, Init. Repts., 197: College Station, TX (Ocean Drilling Program).

Tejada, M.L.G., Mahoney, J.J., Duncan, R.A., and Hawkins, M.P., 1996. Age and geochemistry of basement and alkalic rocks of Malaita and Santa Isabel, Solomon Islands, southern margin of Ontong Java Plateau. J. Petrol., 37:361-394, doi:10.1093/petrology/37.2.361.

Tejada, M.L.G., Mahoney, J.J., Neal, C.R., Duncan, R.A., and Petterson, M.G., 2002. Basement geochemistry and geochronology of Central Malaita, Solomon Islands, with implications for the origin and evolution of the Ontong Java Plateau. J. Petrol., 43:449-484, doi:10.1093/petrology/ 43.3.449.

\section{Authors}

William W. Sager, Department of Oceanography, Texas A\&M University, College Station, TX 77843-3146, U.S.A., e-mail: wsager@tamu.edu.

Takashi Sano, Department of Geology and Paleontology, National Museum of Nature and Science, 4-1-1 Amakubo, Tsukuba 305-0005, Japan, e-mail: sano@kahaku.go.jp.

Jörg Geldmacher, Integrated Ocean Drilling Program, Texas A\&M University, 1000 Discovery Drive, College Station, TX 77845-9547, U.S.A., e-mail:geldmacher@iodp. tamu.edu.

\section{and IODP Expedition 324 Scientists}

